\title{
PREFACE
}

\section{A Novel Approach}

This book offers a novel way of analyzing the problems, challenges, and potentialities of international development: psychoanalysis. Indeed, over the last decade or so, there has been a revitalization of the psychoanalytic perspectiveparticularly the Lacanian one-spearheaded mainly by Slavoj Žižek, but including notable others such as Joan Copjec, Alenka Zupančič, Mladen Dolar, and Todd McGowan, and spurring renewed interest in postcolonial pyschoanalytic thinkers such as Frantz Fanon, Ashis Nandy, Homi Bhabha, and Kalpana Seshadri-Crooks. This book draws on this perspective to analyze how development's unconscious desires "speak out," most often in excessive and unpredictable ways that contradict its outwardly rational declarations but also constitute the grounds for a radical politics.

Tellingly, international development (and social science more generally) has tended to disavow the unconscious. Yet, the theory and practice of development are replete with unacknowledged memories (racism, [neo]colonialism, gender discrimination) and traumatic prohibitions (economic recession, poverty), which show up in fantasies (the exoticized Third World, structural adjustment as universal panacea), obsessions (economic growth, "wars" on poverty or terror), or stereotypes (denigration, infantilization, sexualization, or feminization of the Third World Other). Psychoanalysis aims precisely at teasing out these unconscious processes. It can help explain the gap between development's scientific commitments (e.g., belief in progress, neutrality, objectivity, rationality) and its "irrational" practices (e.g., the seductive draw of narrow capitalistic growth, the fatal pull to aggressive racism, or the blind conformity to bureaucratic procedures or ethnic/religious identities). It can help us understand that development is not only a socioeconomic construction, but also an ideological construction intent on effacing its various internal traumas and contradictions - for example, the way in which development is "naturally" equated with neoliberal growth and liberal democracy, concealing the reality of rapacious capitalism, growing global inequalities and unevenness, and diminishing avenues for political contestation. 
The novelty of the psychoanalytic perspective, as this book explains, lies not simply in its ideology critique, but also in opening up possibilities for radical political change. The unconscious, in other words, is to be seen as not only a basis upon which ideology is constructed, but also a political resource: its excess may well be unpredictable, yet such unpredictability can also be enabling, providing the subject with a means to break through the global capitalist status quo.

This view stands in contrast to Foucauldian discourse analysis, which has tended to dominate critical thinking in Development Studies over the last few decades. While discourse analysis is useful in focusing on power/knowledge dynamics in development, it ignores the fact that such power is able to take hold, expand and, crucially, persist only through unconscious libidinal attachments (e.g., desires, enjoyment). As this book suggests, this neglect leaves discourse analysis with few resources beyond localized resistance to address the structural challenges of global capitalism, depriving it of the radical political possibilities brought to light by psychoanalysis. I suggest, in fact, that local resistance is not only unthreatening to, and tolerated by, the global capitalist order but also psychoanalytically revealing for being an implicit acceptance of this order, often preventing the Left from imagining or struggling for a postcapitalist alternative.

But while Foucauldian-inspired development theorizing constitutes the main intellectual adversary in this book (see chapters 2, 7, 8, and 12), it is not the only one. I also take social construction to task, including its Butlerian performative variant (chapter 8), for yielding to a timid and fragmented feminist politics that may help reproduce the patriarchal capitalist status quo. Moreover, while partial to Marxist political economy for its uncompromising opposition to global capitalism and inequality, I highlight its neglect of the unconscious (chapters 1, 4, 5, and 12), which causes it to underestimate the power and stubbornness of neoliberal development. Instead, I suggest that complementing political economy with "libidinal economy" can not only help better understand how global capitalism reproduces itself, but also bring to the fore the passionate underpinnings (e.g., excess, drive) of any anticapitalist politics.

\section{Book Structure and Cross-Cutting Themes}

The book has a relatively unique structure: the first section is composed of two chapters aimed at introducing the topic (the Lacanian psychoanalytic perspective and what it can contribute to Development Studies) and putting it into context (how the psychoanalytic perspective differs from, and innovates 
politically, the Foucauldian-inspired Post-Development perspective that has tended to dominate critical analysis in international development over the last few decades). The second section, "Keywords/Essays," is a collection of ten chapters applying key psychoanalytic concepts (antagonism, drive, envy, fetish, gaze, gender/sex, etc.) to the field of international development. These chapters are ordered alphabetically according to psychoanalytic keyword, dictionarylike, and used to examine a variety of arguments, examples, and case studies in development (e.g., Eurocentrism, universalism, capitalist accumulation/ growth, structural adjustment, poverty, inequality, participation, technology, corruption, revolution, "race," LGBTI politics, etc.).

This structure is inspired by the influential edited volume The Development Dictionary: A Guide to Knowledge as Power (Sachs 1992), also organized in dictionary-like form; although unlike the latter, which is a collection of essays investigating key concepts in development from a Post-Development perspective ("development," "environment," "economy," "helping," "market," etc.), the idea here is to forefront important psychoanalytic concepts to help us better understand the politics of development.

The latter structure, it should be noted, is what helps explain the choice of subtitle for this book - it is not "A Psychoanalysis of International Development" but "Psychoanalysis and International Development," underscoring psychoanalysis as a well-established field with a range of analytic lenses and concepts that Development Studies would (arguably) do well to take seriously. In other words, while this book does indeed attempt to psychoanalyze development, the idea is also to decenter development (a typically psychoanalytic move!) by foregrounding a Lacanian understanding of the unconscious.

This unconventional structure implies two points. First, the book aims not so much at providing an overarching psychoanalytic argument as introducing some important psychoanalytic concepts- "keywords" - as a way of investigating a variety of problems in international development. The thread that does run through these keywords and essays is the thread of psychoanalysis itself: investigating the unconscious (of international development), that is, the multiple ways in which desire manifests, through processes of displacement, disavowal, envy, fetishism, and so forth. What emerges is how subjects of development do not necessarily seek their own good and often act against their stated intentions. Their unconscious desires are, in this sense, a barrier to their self-identity, impelling them to act contrary to their conscious wishes, obeying a logic of enjoyability, excess, and self-destruction rather than rationality, effectiveness, or humanitarianism.

Second, the book does not aim at comprehensiveness in relation to psychoanalysis (or indeed international development). It is a collection of essays on 
psychoanalytic concepts that, drawing on the recent Lacanian psychoanalytic literature, I see as important, fully acknowledging that other concepts are missing (e.g., aggression, delusion, madness, paranoia, psychosis, sublimation, etc.). Noteworthy in this regard is the fact that there are no exclusive chapter treatments of perhaps the most important Lacanian notions-enjoyment (jouissance), fantasy/ideology, and the Real. This is because they are dealt with in a variety of ways in multiple chapters, and in that sense are crucial cross-cutting themes in the book.

Enjoyment, which denotes not simply pleasure, but excess, to the point of being painful and counterproductive, is integral to almost every chapter. It is a central Lacanian/Žižekian concept that helps elucidate development's many "irrationalities": why people are seduced by capitalist development in spite of its production of inequalities and environmental ills (chapters 1, 2, 4, and 6), why racism endures despite decades of antiracist education (chapters 1, 7, and 11), or why the follies and excesses of development might themselves be the grounds for derailing and transgressing politics as usual (chapters 2, 4, 5, 8, 9, 10 , and 12). An important dimension that I elaborate in the book (chapters 2 , 7, and 12) is what I call "institutional enjoyment": in contrast to (idealized) Weberian conceptions of the state, which seek to ensure a rational and "neutral" functioning of bureaucracies, institutional enjoyment points to the unconscious processes as a result of which the civil service, as much as development nongovernmental organizations (NGOs), derive satisfaction from routine, red tape, and spectacle (e.g., of development interventions in crises such as famines, earthquakes, or war). In several instances, I point out how such satisfaction takes the form of sadomasochistic pleasure-lording bureaucratic power over the poor or sometimes instrumentalizing or even scapegoating them. This helps explain, in my view, not only why institutional power can veer toward the irrational and the authoritarian, but also why red tape-and in our mediatic age, spectacle-persists and grows in spite of repeated attempts at improving efficiency, slashing programs, or better "serving the poor." My claim is that the development institutional machine is a wellspring of pleasure and excess that defies rationality, objectivity, or humanitarianism.

"Fantasy" and "the Real," for their part, are also key notions highlighted throughout this book, the former underlining ways in which development is an ideological construction that attempts to efface its unconscious underpinnings (chapters 1, 2, 3, 6, 7, 10, and 12), the latter pointing to the inherent ruptures and contradictions of ideological formations which threaten to erupt at any moment (chapters 1, 2, 3, 4, 7, 8, 10, and 12). What is crucial about the former, I claim, is that ideological fantasies function at the level not simply of dreams or ideas but of institutional practices: desires and fantasies are exter- 
nalized and materialized in the form of actions and institutional policy-making. This is another way of saying that all material or institutional practiceswhether in international development or otherwise-are psychically charged, that is, they are constructed around, and respond to, various forms of trauma (the Real). It is also a way of conveying that the power, seduction, and rigidity of development practice lies in the disavowed desires that support it. And the wager in the book is that it is because such desires remain unconscious that ideological constructions are so difficult to dismantle. Ideology critique involves, then, not just deconstructing dominant discourses (identifying their gaps, exclusions, etc.), but unearthing and confronting their unconscious processes, as well as our own unconscious investments in them.

But if ideology's endurance and pervasiveness are made possible by its unconscious supports, these same supports are its Achilles's heel. This is to say that the material-discursive apparatus that is development is replete with gaps, excesses, and antagonisms (the Real), which render it insecure and unpredictable, thereby making possible a destabilizing politics. The book makes it a point to take up several of these (radical) political possibilities: ideology critique (chapters 1, 2, 3, 6, 8, and 12), aimed not only at dismantling neoliberalism but, as described above, also at facing up to our own libidinal expenditures in it; the strategy of subaltern mimicry, which strives to hijack state or corporate power and resources for subaltern purposes (chapter 7); a psychoanalytic antiracist politics, that struggles to challenge and recast dominant fantasies (chapter 11); a queer or hysterical Left politics, which attempts to inhabit drive's derailed excess to resist the seductions of neoliberalism and remain uncompromising on the Left desire for a post-capitalist alternative (chapters 4, 9, 10, and 12); and most importantly, a (negative) universal politics (chapters 3,8 , and 12) that bids to bring together a range of actors, based not on their particular identities as workers, women, or queers-which most often divide people along and across North-South lines-but their shared trauma (i.e., the inequalities and dispossession wrought by global capitalism). For, it will surely require nothing less than a series of coordinated and collective assaults, small and large, to (even begin to attempt to) destabilize the ever-changing and revolutionary global order that is capitalism.

Of course, such a panoply of (complementary) psychoanalytically informed political maneuvers is neither definitive nor sufficient, and comes without guarantees. As I emphasize repeatedly throughout the book, each would require tremendous determination and courage, not only to be able to "traverse the fantasy" of capitalist development, but also to fail (and perhaps fail again) while trying. But in any case, as Žižek reminds us (2018), we should not fall into the trap of always having to follow up a negative critique with an uplifting 
political alternative: for the latter may serve as pretext to avoid the true traumas of our times. There is the distinct prospect that, in our current historical conjuncture, no discernible way out can be found, so that assuming the "courage of hopelessness" means neither despairing nor grasping for easy solutions, but rather better confronting the deadlocks of our age, with the hope that something new might emerge. Psychoanalysis may well help point up the political resources available to us in a particular historical-spatial conjuncture, but this does not necessarily mean they are the appropriate resources, that is, that we have meaningfully identified and confronted the conjunctural antagonism, or that we have the collective commitment, courage, and wherewithal to do so.

\section{References}

Sachs, Wolfgang, ed. 1992. The Development Dictionary: A Guide to Knowledge as Power. London: Zed.

Žižek, Slavoj. 2018. The Courage of Hopelessness: Chronicles of a Year of Acting Dangerously. London: Penguin. 